\title{
EFFECTS OF ARBUSCULAR MYCORRHIZAL FUNGI ON TOMATO YIELD AND NUTRIENT UPTAKE UNDER DIFFERENT FERTILIZATION LEVELS
}

\author{
L. Nedorost, R. Pokluda
}

Received: September 13, 2012

\begin{abstract}
NEDOROST, L., POKLUDA, R.: Effect of arbuscular mycorrhizal fungi on tomato yield and nutrient uptake under different fertilization levels. Acta univ. agric. et silvic. Mendel. Brun., 2012, LX, No. 8, pp. 181-186

Effect of the arbuscular mycorrhiza on tomato plants (Lycopersicon lycopersicum) in the pot experiment was studied. Three different fertilization regimes (optimum - H1, stress a - H2, stress b - H3) and three different mycorrhizal treatments (control - Ctrl, Glomus mossae - Gm, Glomus intraradices - Gi) were used. Economical parameter (yield), nutritional characteristic (vitamin C content, phosphates and minerals content, total antioxidant capacity), and level of root colonization were studied. The yield of the tomatoes was influenced by the basic dose of the fertilization, especially in the $\mathrm{H} 2$ and $\mathrm{H} 3$ treatment. The highest yield was in the $\mathrm{H} 2$ treatment in $\mathrm{Gm}$ ( $938 \mathrm{~g}$ per plant). The positive effect of the inoculation resulted in the increased content of the vitamin C. The highest significant influence was observed in the $\mathrm{H} 2$ treatment (plants inoculated with $\mathrm{Gi}$ ) with the average content of the vitamin C 289 mg. $\mathrm{kg}^{-1}$. The average rate of the colonization was in the range from $39 \%$ to $65 \%$.
\end{abstract}

mycorrhiza, vitamin C, TAC, AMF colonization, tomato

A tomato is an important crop throughout the world and it is grown under a wide range of production systems. The tomato (Solanum lycopersicum L.) is very valuable from the perspective of nutritional value, for example it is a source of the different classes of the antioxidants such as carotenoids, ascorbic acid, phenolic compounds, and $\alpha$-tocopherol (Beecher, 1998; Abushita et al., 1997). This is the reason for searching of new opportunities to improve nutritional content in a tomato under lower level of the fertilization. The use of the arbuscular mycorrhizal fungi (AMF) is one of the possibilities. AMF is the most widespread root fungal symbiosis and it is associated with the vast majority of the higher plants. It represents a mutualistic symbiosis between AMF and the roots of terrestrial plants (Smith and Read, 1997). The fungi colonize roots of approximately $90 \%$ of the Earth's land plant species (Gadkar et al., 2001). AMF improves the absorption of the several nutrients, such as phosphorus (Harley and Smith, 1983; AlKaraki and Al- Raddad, 1997; Chandreshekara et al., 1995), nitrogen, potassium, calcium and magnesium (Liu et al., 2002), copper (Gildon and Tinker, 1983) and zinc (Faber et al., 1990; Gildon and Tinker, 1983). AMF can increase content of the antioxidant in inoculated plants (Huang et al., 2011; Talaat and Shawky, 2011). Arbuscular symbiosis can improve a soil structure and protect host plants against the detrimental effects caused by the drought stress (Schreiner et al., 1997).

\section{MATERIALS AND METHODS}

\section{Experimental site, plant and substrate materials}

The pot experiment was located outdoors under the field conditions at the Faculty of Horticulture in Lednice (Location: 4847'54.502"N; 16²8'0.39"E, 
Czech Republic) in 2011. Seeds of Lycopersicon lycopersicum (Solanaceae) cv. "DARINKA Fl" (SEMO a. s.) were sown on $21^{\text {th }}$ March, and seedlings were planted into experimental 10 liter pots on $30^{\text {rd }}$ May. Properties of substrate were: $65 \%$ of dry matter, $\mathrm{pH}$ 5.8, the electric conductance of the substrate was $1.2 \mathrm{mS} . \mathrm{m}^{-1}$ and the basic fertilization of the substrate (from producer) was PG-mix (N-P-K - 14:16:18) 1.5 $\mathrm{kg} / 1000 \mathrm{l}$. The substrate was fertilized, based on a chemical analysis, with $6.4 \mathrm{~g}$ of $\mathrm{CaCO}_{3}$ per pot to achieve $\mathrm{pH}=6.3$.

\section{Experimental design with microbial treatments}

The experiment contained 54 containers with tomato plants under three different fertilization regimes (optimum - $\mathrm{H} 1$, stress $\mathrm{a}-\mathrm{H} 2$, stress $\mathrm{b}-$ $\mathrm{H} 3$ ) and three different treatments (control - Ctrl, G. mosseae BEG95 - Gm, Glomus intraradices BEG140 - Gi.) $10 \mathrm{~g}, 5 \mathrm{~g}$ and $2.5 \mathrm{~g}$ respectively of calcium sulphate (14\% sulfur content) were added in $\mathrm{Hl}$, $\mathrm{H} 2$ and $\mathrm{H} 3$ fertilization treatment respectively. $10 \mathrm{~g}$, $5 \mathrm{~g}$ and $2.5 \mathrm{~g}$ respectively of bone meal (calcium phosphate content of $80 \%$ ) were added in $\mathrm{H} 1, \mathrm{H} 2$ and $\mathrm{H} 3$ fertilization treatment respectively.

Microbial inoculum was supplied by the company Symbiom ltd. The mycorrhizal inoculum ( $\mathrm{Gm}$ and $\mathrm{Gi}$ ) was added as a mixture of the cultivation substrate, colonized roots and mycelium fragments (grown as single AMF cultures on a maize as the host plant for 5 months in zeolite) in a dose of $100 \mathrm{~g}$ per planting hole approx. $3 \mathrm{~cm}$ below each seedling. Each of the 3 mycorrhizal treatments and 3 fertilization regimes was composed of the 6 pot repetitions, each pot contained 1 seedling.

\section{Harvests, plant analyses, mycorrhizal parameters}

The plants were harvested, measured and sampled for the plant analyses in August 2011. Roots of all plants were sampled to determine AMF colonization.

\section{Vitamin C (ascorbic acid) determination}

The concentration of vitamin $\mathrm{C}$ (ascorbic acid) was determined by HPLC according to Arya et al. (2000) with slight modification. Tomato fruit samples were homogenized in a blender with $75 \mathrm{ml}$ of $0.1 \mathrm{M}$ oxalic acid. The homogenate was topped up with oxalic acid to the volume of $100 \mathrm{ml}$, filtered, centrifuged $(3,800 \mathrm{rt} / \mathrm{min}$ for 10 minutes) and the supernatant was used for measurement. The analyses were performed by RP-HPLC in a LCO-101 column placed in an Ecom thermostat $\left(\mathrm{t}=30^{\circ} \mathrm{C}\right)$, mobile phase TBAH (tetrabutylamonium hydroxide) : $0.1 \mathrm{M}$ oxalic acid: water in the ratio of 10:20:70 (v/v/v), flow $0.5 \mathrm{ml} / \mathrm{min}$ at $254 \mathrm{~nm}$ using a UV-VIS detector. The amount of AA was expressed as $\mathrm{mg} .100 \mathrm{~g}^{-1}$ of fresh weight.

\section{Antioxidant capacity determination by FRAP assay}

Tomato fruit samples (10 g) were homogenized in a blender with $30 \mathrm{ml}$ ethyl alcohol (50\% concentration), homogenate was added with ethyl alcohol (50\% concentration) to amount of $50 \mathrm{ml}$, filtered, centrifuged (3,800 rt/min for 10 minutes), and the supernatant was used for the measurement. Total antioxidant capacity (TAC) was determined using the ferric reducing antioxidant power (FRAP) assay developed by Benzie and Strain (1996). In the FRAP assay, reductants ("antioxidants") present in the extract reduce Fe(III)-tripyridyltriazine (TPTZ) complex to its intensely blue ferrous form with an absorption maximum at $593 \mathrm{~nm}$. The working FRAP reagent was prepared fresh on the day of the analysis by mixing acetate buffer, $10 \mathrm{mM}$ TPTZ solution and $20 \mathrm{mM}$ ferric chloride solutions in the ratio of 10:1:1 (v/v/v). The mixture was incubated at $37^{\circ} \mathrm{C}$. The absorbance was monitored for $4 \mathrm{~min}$ in a temperature-controlled cuvette held at $37^{\circ} \mathrm{C}$ using a JENWAY 6100 spectrophotometer (AIR, UK). The final total antioxidant capacity was expressed in $\mathrm{mg}$ equivalent of Trolox in $100 \mathrm{~g}$ of fresh biomass (mg Trolox.100g ${ }^{-1}$ ).

\section{Content of mineral elements, phosphates and sulphites}

Content of $\mathrm{Na}, \mathrm{K}, \mathrm{Ca}, \mathrm{Mg}, \mathrm{PO}_{4}$ and $\mathrm{SO}_{4}$ were determined by the method of capillary isotachophoresis using the IONOSEP 2003 device (RECMAN, CZ) following method described by Blatny et al. (1997). Tomato samples (20 g) were homogenized and diluted with distilled water (1:40, $\mathrm{v}: \mathrm{v})$ and then analysed. The amount of each mineral element was expressed as $\mathrm{mg}$ per $\mathrm{Kg}$ of tomato fruit fresh weight (fw).

\section{Mycorrhizal colonization}

Mycorrhizal root colonization was evaluated in root samples taken from root systems of experimental plants. Ten roots fragments in long $10 \mathrm{~mm}$ were observed from each plant. Samples were stained with $0.05 \%$ trypan blue in lactoglycerol (Koske and Gemma, 1989) and quantified by the modified grid-line intersect method (Giovannetti and Mosse, 1980) using an ocular grid at a 100x magnification.

\section{Statistical Analysis}

The statistical analysis was carried out in Statistica 9 program (StafSoft Inc.1984-2009) using the ANOVA and LSD methods at the significance level of $\mathrm{P}<0.05$. Measure of variability of a mean value throughout the text is expressed as standard deviation.

\section{RESULTS AND DISCUSSION}

First goal of the experiment was to find out if the tomato plants were significantly colonized with 
AMF (Fig. 1). It was expected that a commercial substrate contains only a little amount of AMF. This statement was finally confirmed. Plants from the control treatment had a rate of the colonization in the range from $3.8 \%(\mathrm{H} 1)$ to $5.4 \%(\mathrm{H} 3)$ in average. Plants from mycorrhizal treatment $\mathrm{Gm}$ had a rate of the colonization in the range from $44 \%(\mathrm{Hl})$ to $62 \%$ (H3), and from treatment Gi in the range from $43 \%$ (H1) to $57 \%$ (H3). Karagiannidis et al. (2002) found similar levels of Glomus colonization in a tomato $(49$ $\%)$. Higher level of colonization was found in plants which had a lower dose of the fertilizer. Significant differences were found between mycorrhizal treatments in the fertilizer level $\mathrm{Hl}$ and $\mathrm{H} 3$. A similar conclusion was reached by Hajiboland et al. (2009). He found that rice under optimal conditions of the phosphorus gave worse values of the colonization.

As it is shown in the Fig. 1, a fertilization level had the significantly positive effect on the yield especially on control plants. In the highest level, the yield was in Ctrl 941 g. plant ${ }^{-1}$, in the fertilization level H2 829 g.plant ${ }^{-1}$ only and in H3 777 g.plant ${ }^{-1}$ only. The phosphor fertilization had the positive effect on a production of flower (Poulton et al., 2001), what it was shown in the tomato yield. If the level of the fertilization was lower, the yield was lower as well. This negative effect was reversed with a help of the mycorrhizal fungi. The positive effect of the inoculation was found in the $\mathrm{H} 2$ and $\mathrm{H} 3$ treatment. The highest yield was in the $\mathrm{H} 2$ treatment in the treatment Gm (938g per plant) in comparison to Ctrl (838g per plant), which makes an increase of $10 \%$. In the $\mathrm{H} 3$ treatment, the highest yield was in the variant Gm (913 g per plant) in comparison to control ( $777 \mathrm{~g}$ per plant), with an increase of $14 \%$. Hypothesis, that AMF can improve the yield, is corresponding with many other results, for example Al-Karaki and Clark (1999) or Valentine et al. (2007).

The highest content of vitamin $\mathrm{C}$ (ascorbic acid) was recorded in the variant $\mathrm{H} 2$ (Fig. 2), in the treatment Gi (289 mg. $\left.\mathrm{kg}^{-1}\right)$, an increase of $20 \%$ in comparison to the Ctrl $\left(230 \mathrm{mg} \cdot \mathrm{kg}^{-1}\right)$. However, the second highest content (265 mg. $\left.\mathrm{kg}^{-1}\right)$ of vitamin $\mathrm{C}$ was found in non mycorrhizal treatment Ctrl in fertilization $\mathrm{Hl}$. The content of vitamin $\mathrm{C}$ was decreased with the decreasing level of the fertilization. In the Ctrl treatment and $\mathrm{H} 3$ level of fertilization the lowest content of vitamin C (212 $\mathrm{mg} . \mathrm{kg}^{-1}$ ) was found. The microbial treatment was able to increase the content of vitamin $\mathrm{C}$ in a lower level of the fertilization $\mathrm{H} 3$ in comparison to Ctrl. The content of vitamin C was 16\% (Gi) and $13 \%$ (GM) higher than Ctrl. The ability to increase the vitamin $\mathrm{C}$ content by mycorrhiza describes Dey et al. (2005).

The positive effect of the inoculation on the antioxidant capacity was found in the variant with the highest dose of the fertilization mainly (Fig. 2). In the experiment, treatment $\mathrm{Gi}$ in variant $\mathrm{Hl}(17.6 \mathrm{mg}$ Trolox.100 $\left.\mathrm{g}^{-1}\right)$ had the best result, in comparison to Ctrl (15.7 mg Trolox.100 g $\mathrm{g}^{-1}$ ), with an increase of $10 \%$. Huang (2011) also describes the positive effect of the mycorrhiza on the content of the antioxidants
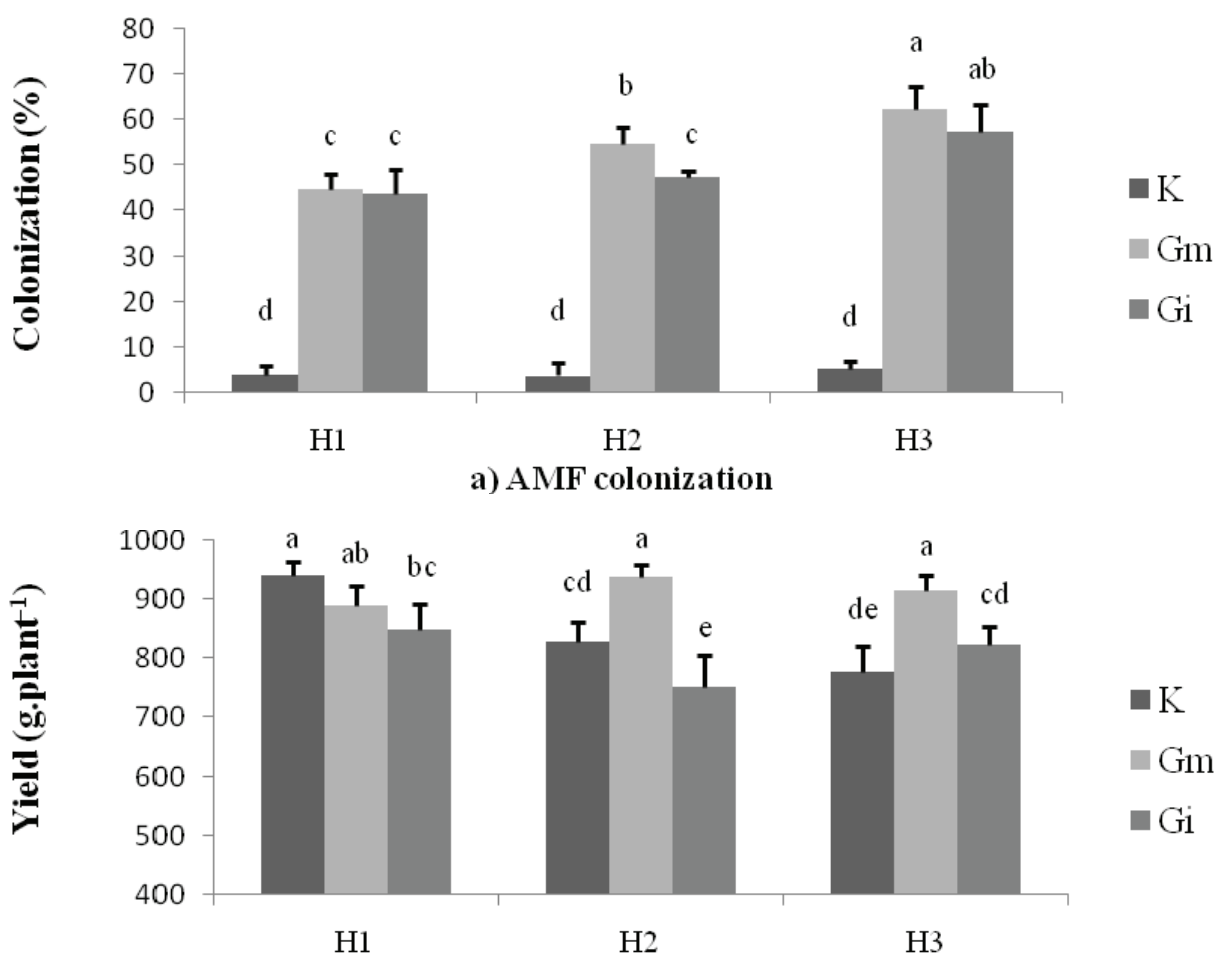

b) Yield (fresh weight)

1: a) AM colonization, b) Yield fresh weight. Means \pm SD, columns marked with the same letters are not significantly different at the level $P<0.05$, LSD Test, $n=6$ 


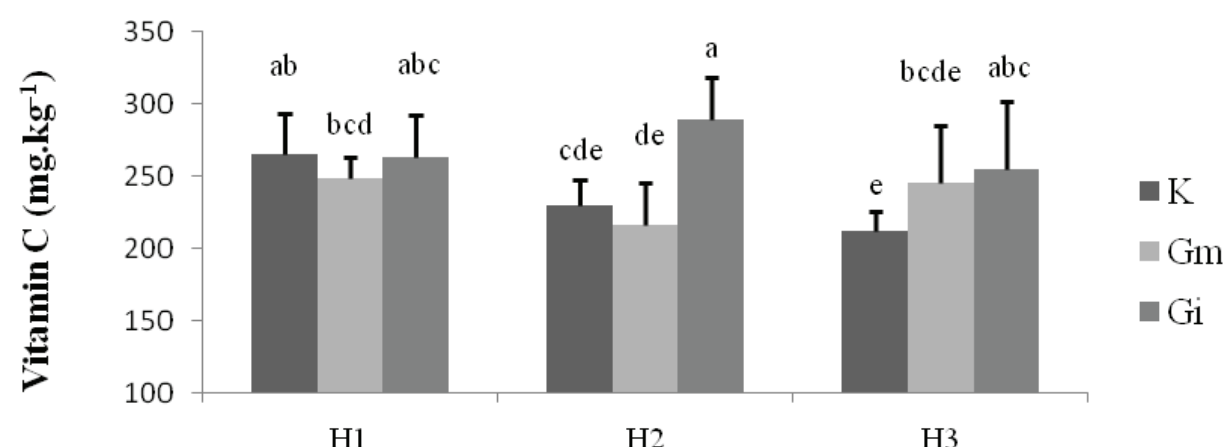

a) Vitamin $\mathrm{C}$

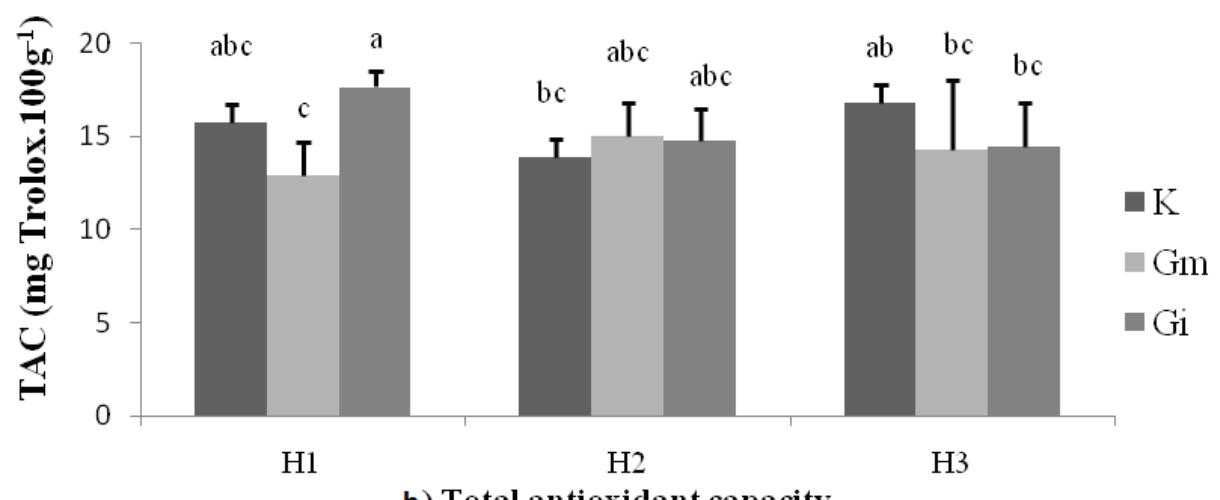

b) Total antioxidant capacity

2: a) Vitamin C, b) TAC. Means \pm SD, columns marked with the same letters are not significantly different at the level $P<0.05$, LSD Test, $n=6$

in a watermelon. In the treatment $\mathrm{H} 2$, differences between treatments were not significant. In H3 variant, the second highest content of antioxidants in the non mycorrhizal plants was found $(16.8 \mathrm{mg}$ Trolox.100 $\left.\mathrm{g}^{-1}\right)$. The content of the antioxidant in Gi was $14.4 \mathrm{mg}$ Trolox.100 $\mathrm{g}^{-1}$ and in $\mathrm{Gm} 14.3 \mathrm{mg}$ Trolox.100 $\mathrm{g}^{-1}$ only. According to our results, it seems there is a trend the mycorrhizal treatment Gi increases the content of antioxidants especially in the variant of higher doses of the fertilizer. The individual effect of the different fertilization may influence the content of the TAC on vegetables. Albrechtova et al. (2012) described that the application of the mycorrhiza can increase activity of antioxidants in an onion.

Another part of the experiment was determining the content of phosphates, sulphates and minerals in fruits. Results are showed in Tab I. The highest content of $\mathrm{PO}_{4}$ in the fruit was found in $\mathrm{Hl}$ level of the fertilization and in Gi treatment, an increase in comparison to the Ctrl $\mathrm{Hl}$ represented $63 \%$. The treatment $\mathrm{Gm} \mathrm{Hl}$ had also very good result. The content of $\mathrm{PO}_{4}$ was $1369 \pm 210 \mathrm{mg} \cdot \mathrm{kg}^{-1}$. It is significantly more than in $\mathrm{Ctrl} \mathrm{Hl}$. In other levels of the fertilization $\mathrm{H} 2$ and $\mathrm{H} 3$, no significant differences were found between treatments. The significantly variance was found only between levels of the fertilization, the content of $\mathrm{PO}_{4}$ was the highest with the highest level of the fertilization. The mycorrhizal treatment was able to increase the content of $\mathrm{PO}_{4}$ only in the highest fertilization $\mathrm{Hl}$.
Many authors descript the ability of the mycorrhizal fungi to increase the content of $\mathrm{P}$, for example Liu et al. (2007) or Valentine et al. (2007).

$\mathrm{SO}_{4}$ analysis showed the positive effect of the mycorrhiza, mainly in the $\mathrm{Hl}$ level of the fertilization. Plants from the treatment $\mathrm{GiHl}$ and $\mathrm{Gm}$ $\mathrm{Hl}$ had the significantly highest content of $\mathrm{SO}_{4}$ than plants in Ctrl $\mathrm{Hl}$. The significantly highest content of $\mathrm{SO}_{4}$ in the variant $\mathrm{H} 2$ had also the treatment $\mathrm{Gm}$ in comparison to Ctrl H2. No significant difference was found between treatments in $\mathrm{H} 3$ level of the fertilization. There is not confirmed effect of the mycorrhiza on the content of $\mathrm{SO}_{4}$.

No stronger influence of the fertilization on the content of $\mathrm{Ca}$ was found, but the influence of the treatment was significant. The highest content of Ca was found in Gm treatment in average $173 \pm 12$ mg. $\mathrm{kg}^{-1}$ in comparison to Ctrl (122 \pm 17 mg.kg- in average), which makes an increase of $41 \%$. In the treatment Gi (154 $\pm 5 \mathrm{mg} \cdot \mathrm{kg}^{-1}$ in average) was found also the highest content of calcium, in average 26\% more than in Ctrl. The positive effect of the mycorhiza to the content of calcium observed also Seleh et al. (2006). The positive influence of the mycorrhiza on maize was confirmed in his study.

No significant difference was found in the analysis of $\mathrm{K}, \mathrm{Na}, \mathrm{Mg}$ (Tab. I). The highest non significant different in the content of $\mathrm{K}$ was found in the treatment $\mathrm{Gi} \mathrm{H}$ 3. In the treatment $\mathrm{Gm} \mathrm{H1}$, the highest non significant content of Na was observed. The content of $\mathrm{Mg}$ was highest in the treatment 
Effects of arbuscular mycorrhizal fungi on tomato yield and nutrient uptake under different fertilization levels 185

I: Means $\pm S D$, columns marked with the same letters are not significantly different at the level $P<0.05, L S D$ Test, $n=6$, fw - fresh weight

\begin{tabular}{|c|c|c|c|c|c|c|c|}
\hline $\begin{array}{l}\text { microbial } \\
\text { treatment }\end{array}$ & fertilization & $\begin{array}{c}\mathrm{PO}_{4} \\
\left(\mathrm{mg} \mathrm{kg}^{-1} \mathrm{fw}\right) \\
\end{array}$ & $\begin{array}{c}\mathrm{SO}_{4} \\
\left(\mathrm{mg} \mathrm{kg}^{-1} \mathrm{fw}\right)\end{array}$ & $\begin{array}{c}K \\
\left(\mathrm{mg} \cdot \mathrm{kg}^{-1} \mathrm{fw}\right)\end{array}$ & $\begin{array}{c}\mathrm{Na} \\
\left(\mathrm{mg} \mathrm{kg}^{-1} \mathrm{fw}\right) \\
\end{array}$ & $\begin{array}{c}\mathrm{Ca} \\
\left(\mathrm{mg} \cdot \mathrm{kg}^{-1} \mathrm{fw}\right) \\
\end{array}$ & $\begin{array}{c}\mathrm{Mg} \\
\left(\mathrm{mg} \mathrm{kg}^{-1} \mathrm{fw}\right)\end{array}$ \\
\hline \multirow[t]{3}{*}{ Ctrl } & H1 & $995 \pm 136 b$ & $450 \pm 66 b$ & $1685 \pm 152 \mathrm{a}$ & $185 \pm 22 \mathrm{a}$ & $121 \pm 17 \mathrm{de}$ & $114 \pm 11 \mathrm{a}$ \\
\hline & H2 & $589 \pm 268 \mathrm{c}$ & $17 \pm 3 \mathrm{~d}$ & $1773 \pm 201 \mathrm{a}$ & $167 \pm 24 \mathrm{a}$ & $130 \pm 11 \mathrm{cde}$ & $109 \pm 10 \mathrm{a}$ \\
\hline & H3 & $412 \pm 151 \mathrm{c}$ & $13 \pm 8 d$ & $1573 \pm 73 a$ & $185 \pm 18 \mathrm{a}$ & $117 \pm 25 \mathrm{e}$ & $113 \pm 11 \mathrm{a}$ \\
\hline \multirow[t]{3}{*}{ Gi } & H1 & $1626 \pm 226 \mathrm{a}$ & $671 \pm 31 \mathrm{a}$ & $1668 \pm 183 \mathrm{a}$ & $185 \pm 36 \mathrm{a}$ & $162 \pm 3 b$ & $118 \pm 5 \mathrm{a}$ \\
\hline & H2 & $611 \pm 51 \mathrm{c}$ & $175 \pm 54 \mathrm{c}$ & $1592 \pm 131 \mathrm{a}$ & $175 \pm 15 \mathrm{a}$ & $143 \pm 2 \mathrm{bcd}$ & $107 \pm 5 \mathrm{a}$ \\
\hline & H3 & $436 \pm 32 c$ & $56 \pm 68 d$ & $1800 \pm 139 a$ & $181 \pm 21 \mathrm{a}$ & $157 \pm 3 b$ & $118 \pm 6 \mathrm{a}$ \\
\hline \multirow[t]{3}{*}{ Gm } & H1 & $1369 \pm 210 \mathrm{a}$ & $653 \pm 81 \mathrm{a}$ & $1774 \pm 76 \mathrm{a}$ & $192 \pm 17 \mathrm{a}$ & $211 \pm 8 \mathrm{a}$ & $120 \pm 6 \mathrm{a}$ \\
\hline & H2 & $503 \pm 35 c$ & $462 \pm 50 \mathrm{~b}$ & $1653 \pm 144 \mathrm{a}$ & $172 \pm 17 \mathrm{a}$ & $158 \pm 15 b$ & $110 \pm 11 \mathrm{a}$ \\
\hline & H3 & $406 \pm 63 \mathrm{c}$ & $28 \pm 36 \mathrm{~d}$ & $1725 \pm 169 \mathrm{a}$ & $182 \pm 16 \mathrm{a}$ & $151 \pm 15 b c$ & $116 \pm 6 \mathrm{a}$ \\
\hline
\end{tabular}

Gm Hl. This finding doesn't correspond with the conclusion of the other authors, for example Liu et al. (2002) said that AMF can improve the uptake of $\mathrm{K}, \mathrm{Ca}$, and $\mathrm{Mg}$ from soil.

\section{CONCLUSIONS}

The yield of the tomatoes was influenced by the basic dose of the fertilization, especially in the $\mathrm{H} 2$ and $\mathrm{H} 3$ variant. The highest yield was in the $\mathrm{H} 2$ variant in the variant $\mathrm{Gm}$ (938g per plant) in comparison to Ctrl (838g per plant), which makes the increase of $10 \%$. In the $\mathrm{H} 3$ variant, the highest yield was in the variant $\mathrm{Gm}$ (913 g per plant) in comparison to the control (782g per plant), which is an increase of $14 \%$. The positive effect of the inoculation resulted in the increased content of the vitamin C. The most significant influence was observed in the $\mathrm{H} 2$ variant (plants inoculated with Gi) with the average content of the vitamin C 289 $\mathrm{mg} \cdot \mathrm{kg}^{-1}$. The increase in the comparison to the control (230 mg. $\mathrm{kg}^{-1}$ ) represented $20 \%$. The average rate of the colonization was in the range from $39 \%$ to $65 \%$.

\section{SUMMARY}

The pot experiment was located outdoors under the field conditions at the Faculty of Horticulture in Lednice. The experiment contained 54 containers with tomato plants under three differentfertilization regimes (optimum - H1, stress a - H2, stress b - H3) and three different treatments (control - Ctrl, G. mosseae BEG95 - Gm, Glomus intraradices BEG140 - Gi). $10 \mathrm{~g}$, $5 \mathrm{~g}$ and $2.5 \mathrm{~g}$ respectively of calcium sulphate (14\% sulfur content) were added in $\mathrm{Hl}, \mathrm{H} 2$ and $\mathrm{H} 3$ fertilization treatment respectively. $10 \mathrm{~g}$, $5 \mathrm{~g}$ and $2.5 \mathrm{~g}$ respectively of bone meal (calcium phosphate content of $80 \%$ ) were added in $\mathrm{H} 1, \mathrm{H} 2$ and H3 fertilization treatment respectively.

Economical parameter (yield), nutritional characteristic (vitamin C content, phosphates and minerals content, total antioxidant capacity), and level of root colonization were studied. The results of this study indicate that level of $\mathrm{P}$ fertilization can influence the level of the mycorrhizal colonization. The colonization was higher with a lower level of $\mathrm{P}$ fertilization. The yield of tomato was positively influenced by the mycorrhizal treatment mainly at a lower level of the fertilization. The content of vitamin $C$ was influenced mainly with the mycorrhizal treatment, notably at a lower level of the fertilization. The positive effect of inoculation on the antioxidant capacity was mainly found in the treatment with the highest dose of the fertilization. At lower level of fertilization, the highest content of TAC was found in control plants. The content of $\mathrm{PO}_{4}$ was positively influenced by the mycorrhizal treatment only in the highest level of the fertilization. In another level of fertilization, no differences were found between treatments, the highest content of $\mathrm{PO}_{4}$ was in accordance to the highest level of the fertilization as well. The analysis of $\mathrm{SO}_{4}$ showed the positive effect of the mycorrhiza, mainly in a higher level of the fertilization. In the analysis of $\mathrm{K}, \mathrm{Na}, \mathrm{Mg}$, no significant differences were found.

\section{REFERENCES}

ABUSHITA, A. A., HEBSHI, E. A., DAOOD, H. G., BIACS, P. A., 1997: Determination of antioxidant vitamins in tomatoes. Food Chem., 60:207-212.

ALBRECHTOVA, J., LATR, A., NEDOROST, L., POKLUDA, R., POSTA, K. and VOSATKA, M.,
2012: Dual inoculation with mycorrhizal and saprotrophic fungi applicable in sustainable cultivation improves the yield and nutritive value of onion. The Scientific World Journal, art. No. 374091. AL-KARAKI, G. N. and AL-RADDAD, A., 1997: Effects of arbuscular fungi and drought stress on growth and nutrient uptake of two wheat 
genotypes differing in their drought resistance. Mycorrhiza, 7: 83-88.

AL-KARAKI, G. N. and CLARK, R. B., 1999: Mycorrhizal influence on protein and lipid of durum beat grown at different soil phosphorus levels. Mycorrhiza, 9 (2): 97-101.

ARYA, S. P., MAHAJAN, M., JAIN, P., 2000: Non-spectrophotometric methods for the determination of Vitamin C. Analytica Chimica Acta, 417 (1): 1-14.

BEECHER, G. R., 1998: Nutrient content of tomatoes and tomato products. Proc. Soc. Exp. Biol. Med., 218: 98-100.

BENZIE, I. F. F. and STRAIN, J. J., 1996: The ferric reducing ability of plasma (FRAP) as a measure of 'antioxidant power'. The FRAP assay. Analytical Biochemistry, 239 (1): 70-76.

BLATNY, P., KVASNICKA, F., LOUCKA, R., SAFAROVA, H., 1997: Determination of Ammonium, Calcium, Magnesium, and Potassium in Silage by Capillary Isotachophoresis. Journal of Agricultural and Food Chemistry, 45 (9): 3554-3558.

CHANDRESHEKARA, C. P., PATIL, V. C., SREENIVASA, M. N., 1995: VA-mycorrhiza mediated $\mathrm{P}$ effect on growth and yield of sunflower (Helianthus annus L.) at different P levels. Plant Soil, 176: 325-328.

DEY, P., RAI, M., KUMAR, S., NATH, V., DAS, B., REDDY, N. N., 2005: Effect of biofertilizer on physico-chemical characteristics of guava (Psidium guajava) fruit. Indian Journal of Agricultural Sciences, 75 (2): 95-96.

FABER, B. A., ZASOSKI, R. J., BURAU, R. G., URIU, K., 1990: Zinc uptake by corn as affected by vesicular-arbuscular mycorrhizae. Plant Soil, 129: 121-130.

GADKAR, V., DAVID-SCHWARTZ, R., KUNIK, T., KAPULNIK, Y., 2001: Arbuscular mycorrhizal fungal colonization. Factors involved in host recognition. Plant Physiology, 127(4): 1493-1499.

GILDON, A. and TINKER, P. B., 1983: Interactions of vesicular-arbuscular mycorrhizal infection and heavy metals in plants. I. The effects of heavy metals on the development of vesiculararbuscular mycorrhizas. New Phytol., 95: 247-261.

GIOVANNETTI, M. and MOSSE, B., 1980: Evaluation of techniques for measuring vesiculararbuscular mzcorrhiyal infection in roots. New Phytologist, 84 (3): 489-500.

HAJIBOLAND, R., ALIASGHARZAD, N., BARZEGHAR, R., 2009: Influence of arbuscular mycorrhizal fungi on uptake of $\mathrm{Zn}$ and $\mathrm{P}$ by two contrasting rice genotypes. Plant, Soil and Environment, 55 (3): 93-100.
HARLEY, J. L. and SMITH, S. E., 1983: Mycorrhizal symbiosis. Academic Press, London UK.

HUANG, Z., ZOU, Z., HE, C., HE, Z., ZHANG, Z., LI, J., 2011: Physiological and photosynthetic responses of melon (Cucumis melo L.) seedlings to three Glomus species under water deficit. Plant and Soil, 339 (1): 391-399.

KARAGIANNIDIS, N., BLETSOS, F., STAVROPOULOS, N., 2002: Effect of Verticillium wilt (Verticillium dahliae Kleb.) and mycorrhiza (Glomus mosseae) on root colonization, growth and nutrient uptake in tomato and eggplant seedlings. Scientia Horticulturae, 94: 145-156.

KOSKE, R. E. and GEMMA, J. N., 1989: A modified procedure for staining roots to detect VA mycorrhizas. Mycological Research, 92 (4): 486-505.

LIU, A., HAMEL, C., ELMI, A., COSTA, C., MA, B., SMITH, D. L., 2002: Concentrations of K, Ca and $\mathrm{Mg}$ in maize colonised by arbuscular mycorrhizal fungi under field conditions. Can. J. Soil Sci., 82(3): 271-278.

LIU, J., WU, L., WEI, S., XIAO, X., SU, C., JIANG, P., SONG, Z., WANG, T., YU, Z., 2007: Effects of arbuscular mycorrhizal fungi on the growth, nutrient uptake and glycyrrhizin production of licorice (Glycyrrhiza uralensis Fisch). Plant Growth Regulation, 52(1): 29-39.

POULTON, J. L., KOIDE, R. T., STEPHENSON, A. G., 2001: Effects of mycorrhizal infection, soil phosphorus availability and fruit production on the male function in two cultivars of Lycopersicon esculentum. Plant, Cell and Environment, 24 (8): 841-849.

SCHREINER, R. P., MIHARA, K. L., MC DANIEL, H., BETHLENFALVAY, G. J., 1997: Mycorrhizal fungi influence plant and soil functions and interactions. Plant Soil, 188: 199-209.

SELEH, M and SALEH, AL-GARNI., 2006: Influence of Malathion and Mancozeb on Mycorrhizal Colonization and Growth of Zea mays and Vicia faba. World Journal of Agricultural Sciences, 2 (3): 303-310.

SMITH, S. E. and READ, D. J., 1997: Mycorrhizal symbiosis. Academic Press, London.

TALAAT, N. B. and SHAWKY, B. T., 2011: Influence of arbuscular mycorrhizae on yield, nutrients, organic solutes, and antioxidant enzymes of two wheat cultivars under salt stress. Journal of Plant Nutrition and Soil Science, 174 (2): 283-291.

VALENTINE, A. J. and KLEINERT, A., 2007: Respiratory responses of arbuscular mycorrhizal roots to short-term alleviation of $\mathrm{P}$ deficiency. Mycorrhiza, 17 (2): 137-143.

\section{Address}

Ing. L'udovít Nedorost, doc. Ing. Robert Pokluda, Ph.D., Ústav zelinářství a květinářství, Mendelova univerzita v Brně, Valtická 337, 69144 Lednice, Česká republika, e-mail: xnedoros@node.mendelu.cz, pokluda@ mendelu.cz 